\title{
Evaluation of anxiety and depression in patients with thyroid function disorder
}

(iD) Nurcan Akbas Gunes ${ }^{1}$

1. Bolu Abant Izzet Baysal University, Faculty of Medicine, Department of Family Medicine, Bolu, Turkey

http://dx.doi.org/10.1590/1806-9282.66.7.979

\section{SUMMARY}

OBJECTIVES: We aim to determine the anxiety and depression levels of patients treated for hypothyroidism who assumed euthyroid status. These patients also frequently attend family medicine outpatient clinics.

METHODS: This study was conducted on 76 euthyroid volunteer participants (patient groups) who were treated for hypothyroidism and followed-up and 22 healthy volunteers (control group). Questionnaires were administered to all participants to assess anxiety and depression levels. The Beck Depression Inventory (BDI) and Beck Anxiety Inventory (BAI) were applied to all the groups. In addition, BAI sub-parameters were evaluated in detail.

RESULTS: At least mild depression was detected in 54.5\% of the first group, 41.7\% of the second group, and $33.3 \%$ of the third group. When the BDI and BAI total scores of the participants in different groups were compared, statistically significant differences were determined. Statistically significant results were detected related to different BAI sub-parameters between the patient groups and in comparison to the fourth group.

CONCLUSIONS: We found that patients were predisposed to anxiety and depression even if they were euthyroid. When the sub-parameters of BAI were evaluated in detail, we observed that the duration of the disease significantly affected some anxiety-related symptoms.

KEYWORDS: Anxiety. Depression. Thyroid diseases.

\section{INTRODUCTION}

It is known there is a relationship between brain functions and thyroid hormone levels. Intracranial receptors and intracerebral biochemical reactions are closely related to thyroid hormones. There is also a common relationship between thyroid hormone levels and anxiety-depression in hypothyroid patients ${ }^{1}$. It is known that anxiety disorder, major depression, and psychosis are seen in an average of $30 \%, 40 \%$, and $5 \%$ of the patients with hypothyroidism ${ }^{2}$. It has been also reported that thyroid dysfunction may affect mood and the progression of mood disorders.
Initially, nonspecific symptoms are seen. However, depression, forgetfulness, deceleration in thought, and concentration problems may be seen in later stages in hypothyroidism. In severe clinical conditions, psychotic symptoms may appear ${ }^{3}$. A depressive mood is the most common psychiatric symptom in patients with thyroid dysfunction. In addition, anxiety and sleep disorders are common in these patients. Some of these signs and disorders persist after thyroid functions have improved. Most of the symptoms disappear after treatment ${ }^{4}$. 
Chronic hypothyroidism may cause permanent cognitive changes ${ }^{5}$. In patients with thyroid dysfunction, many symptoms, such as dyspnoea, sweating, and palpitations may be observed in patients with panic attacks. Nevertheless, anxiety disorders associated with thyroid dysfunction still remain unclear ${ }^{6}$.

Patients with thyroid dysfunction frequently attend family medicine outpatient clinics. Therefore, we aimed to determine the anxiety and depression levels of the patients who were treated due to hypothyroidism and became euthyroid in terms of family medicine. In addition, we aimed to raise awareness among family physicians about mood disorders that may develop due to thyroid dysfunctions. Also, we aimed to evaluate the sub-parameters of the Beck Anxiety Scale (BAI) in detail. When the literature was evaluated, we did not find any studies in which the sub-parameters of the BAI were evaluated in detail in patients with thyroid disorders.

\section{METHODS}

\section{Study population}

Necessary permissions were obtained (2018-32014). This study was conducted as a prospective and randomized controlled study. The study was performed to determine the anxiety and depression levels of patients who were followed up due to thyroid dysfunction in our family medicine outpatient clinic.

All patients who were followed-up and treated for hypothyroidism between November 1, 2018, and May 1,2019 , were evaluated. 76 patients were included in the study.

The 76 volunteered participants who were treated and followed-up for hypothyroidism were included in the study. In addition, 22 healthy volunteers between the ages of 25-45 years were included as a control group. Participants in the control group were randomly selected.

Patients who were followed-up for hypothyroidism, received thyroid hormone replacement therapy, and had euthyroidism based on thyroid function test results were included in our study. Complete blood counts and the biochemical test results of the participants were evaluated. Participants with additional hematological disorders were excluded from the study. In addition, participants who were diagnosed with systemic diseases such as hypertension (HT) or diabetes mellitus (DM) during the study and who had a history of using anti-depressants or a different psychiatric drug within the previous year were excluded. The control group consisted of healthy participants who had no health problems.

\section{Patient evaluation scales used in the study}

The participants in the patient group were evaluated for age, gender, duration of thyroid disease in years, and whether they were attending regular follow-ups. Then, the BAI and Beck Depression Inventory (BDI) were applied to the volunteers in the patient and control groups.

The patient group was divided into three subgroups. Group 1 consisted of euthyroid patients who were followed-up for 1 year due to thyroid dysfunction. Patients with euthyroid status followed-up for at least 5 years due to thyroid dysfunction who become euthyroid constituted Group 2. Patients with euthyroid status followed-up for at least 10 years due to thyroid dysfunction were included in Group 3. The healthy volunteers constituted Group 4.

The BAI and BDI total scores were compared between the groups. The differences in the BAI sub-parameters between groups were also analyzed in detail. The sub-parameters of the BAI included in the evaluation are presented in Table 1.

TABLE 1. THE SUB-PARAMETERS OF THE BECK ANXIETY SCALE (BAI) USED AND EVALUATED IN THE STUDY

\begin{tabular}{l} 
Sub-parameters of the BAI \\
\hline Tingling or numbness in any of your body parts? \\
\hline Feeling hot? \\
\hline Wobbliness of legs \\
\hline Unable to relax \\
\hline Fear of the worst happening \\
\hline Feeling dizzy or lightheaded \\
\hline Heart pounding/racing \\
\hline Feeling unsteady \\
\hline Feeling terrified or afraid \\
\hline Nervousness \\
\hline Feeling of choking \\
\hline Hands trembling \\
\hline Feeling shaky/unsteady \\
\hline Fear of losing control \\
\hline Difficulty in breathing \\
\hline Fear of dying \\
\hline Being scared \\
\hline Indigestion \\
\hline Fainting/lightheaded \\
\hline Facial flushing \\
\hline Sweating (unrelated to environment temperature) \\
\hline
\end{tabular}




\section{Statistical Analysis}

Numerical data were calculated as arithmetic mean \pm standard deviation and percentage (\%). The Chi-square test and T-test were used to compare the data between the groups. In addition, Cronbach's alpha value was calculated in a reliability analysis because our study was a survey. $\mathrm{p}<0.05$ was considered statistically significant. Data were analyzed using the SPSS v21.

\section{RESULTS}

The mean age of the patient groups was $39.05 \pm 5.9$ (min: 23, max: 45) and the control group was $38.73 \pm$ 5.71 (min: 25, max: 45 ) years. Sixty-four (84.2\%) female and $12(15.8 \%)$ male participants were included in the patient group. Sixteen (72.7\%) female and 6 (27.3\%) male participants were in the control group. There was no statistically significant difference between the groups in terms of age, education level, and gender. The Cronbach's alpha value found was $0.876(>0.7)$.

BDI scores of $\geq 14$ points were detected in the respective number of patients in groups, and at least mild depression was detected in these patients. The total scores of BAI and BDI in the patient groups were evaluated; the mean BAI and BDI scores of the groups were estimated. The mean BAI score of the 76 participants was determined as $14.53 \pm 9.39$. The mean BAI score of the 22 participants in the control group was found to be $4.36 \pm 3.34$. The mean BDI score of the 76 participants was $13.66 \pm 8.09$. The mean BDI score of the 22 participants in the control group was $6.68 \pm$ 2.93 (Table 2).

When evaluating the effectiveness of rates of patients' regular attendance to the physicians' to control anxiety and depression in the patient groups, the mean BAI score of 50 (65.8\%) participants who regularly attended their check-up visits was $13.36 \pm$ 8.19 , while the $26(34.2 \%)$ participants who did not regularly attend to their check-up had a BAI score of $16.77 \pm 11.39$. In addition, the mean BDI score of 50 (65.8\%) participants who had attended their regular follow-up visits was $13.24 \pm 7.34$, and the BDI score of 26 (34.2\%) participants who did not regularly attend their control visits was $14.46 \pm 9.64$. When evaluated statistically, it was concluded that attending regular control visits had no effect on the severity of anxiety and depression $(\mathrm{p}=0.11, \mathrm{p}=0.390)$.

Statistical evaluation data of the Beck Anxiety Inventory (BAI) sub-parameters between the groups are presented in Table3. The mean BDI and BAI scores of each group are also presented in Figures 1 and 2.

\section{DISCUSSION}

In the clinical practice of family medicine, there are many patients with thyroid dysfunction who become euthyroid and are followed-up with drug therapy. Therefore, we think that family physicians should also evaluate whether these patients are affected psychologically.

Thyroid hormones have an important role in many organ functions and their deficiencies cause diseases of a wide clinical spectrum ${ }^{7}$. The rate of psychiatric symptoms is between $2-12 \%$ in these patients ${ }^{8}$. In cases of acute hypothyroidism, anxiety rates are in the range of $30-40 \%{ }^{9}$. In this study, we mainly evaluated the relationship between anxiety and depression in patients with euthyroid status following thyroid hormone replacement therapy. Also, in the literature, BAI sub-parameters in different disease states have been evaluated in detail ${ }^{10}$. However, there are no studies evaluating the sub-parameters of BAI in individuals with thyroid dysfunction who achieved euthyroid status with treatment. In a

TABLE 2. BECK DEPRESSION SCALE (BDI) AND BECK ANXIETY SCALE (BAI) MEAN SCORES AND STANDARD DEVIATION (SD) IN EACH GROUP, AND NUMBER OF PATIENTS WITH BDI SCORES OF $\geq 14$ POINTS IN GROUPS

\begin{tabular}{|c|c|c|c|c|c|}
\hline BAI & & & $N$ & Mean \pm SD & \\
\hline & $\begin{array}{l}\text { Patient } \\
\text { Group }\end{array}$ & Group 1a & 22 & $16.27 \pm 11.01$ & \\
\hline & & Group 2b & 24 & $12 \pm 6.71$ & \\
\hline & & Group 3c & 30 & $15.27 \pm 10.13$ & \\
\hline & & Total & 76 & $14.53 \pm 9.39$ & \\
\hline & $\begin{array}{l}\text { Control } \\
\text { Group }\end{array}$ & Group 4d & 22 & $4.36 \pm 3.34$ & \\
\hline \multirow[t]{6}{*}{$\mathrm{BDI}$} & & & $N$ & & $\begin{array}{l}N(B D I \\
\text { scores of } \\
\geq 14)\end{array}$ \\
\hline & $\begin{array}{l}\text { Patient } \\
\text { Group }\end{array}$ & Group 1 & 22 & $15 \pm 7.23$ & $12(54.5 \%)$ \\
\hline & & Group 2 & 24 & $13.33 \pm 8.16$ & $10(41.7 \%)$ \\
\hline & & Group 3 & 30 & $14.75 \pm 9.19$ & $10(33.3 \%)$ \\
\hline & & Total & 76 & $13.66 \pm 8.09$ & \\
\hline & $\begin{array}{l}\text { Control } \\
\text { Group }\end{array}$ & Group 4 & 22 & $6.68 \pm 2.93$ & \\
\hline
\end{tabular}

a- Euthyroid patients who were followed-up for 1 year due to thyroid dysfunction (Group 1); b- Patients with euthyroid status followed-up for at least 5 years due to thyroid dysfunction and who became euthyroid constituted Group2; c- Patients with euthyroid status followed-up for at least 10 years due to thyroid dysfunction were included in Group 3; d-The healthy volunteers constituted the control group (Group 4) 
TABLE 3. STATISTICAL EVALUATION DATAS OF THE BECK ANXIETY INVENTORY (BAI) SUB-PARAMETERS BETWEEN GROUPS

\begin{tabular}{|c|c|c|c|c|c|c|}
\hline & P1 & P2 & P3 & P4 & P5 & P6 \\
\hline Tingling or numbness in any of your body parts? & 0,722 & 0,422 & 0,013 & 0,404 & 0,022 & 0,330 \\
\hline Feeling hot? & 0,022 & 0,000 & 0,000 & 0,152 & 0,318 & 0,740 \\
\hline Wobbliness of legs & 0,000 & 0,000 & 0,001 & 0,769 & 0,292 & 0,360 \\
\hline Unable to relax & 0,000 & 0,000 & 0,000 & 0,000 & 0,366 & 0,014 \\
\hline Fear of worst happening & 0,019 & 0,069 & 0,008 & 0,408 & 0,845 & 0,299 \\
\hline Feeling Dizzy or lightheaded & 0,023 & 0,016 & 0,001 & 0,614 & 0,558 & 0,195 \\
\hline Heart pounding / racing & 0,000 & 0,000 & 0,000 & 0,296 & 0,455 & 0,820 \\
\hline Feeling unsteady & 0,000 & 0,000 & 0,000 & 0,838 & 0,386 & 0,381 \\
\hline Feeling terrified or afraid & 0,000 & 0,000 & 0,000 & 0,440 & 0,081 & 0,431 \\
\hline Nervousness & 0,194 & 0,007 & 0,067 & 0,481 & 0,898 & 0,453 \\
\hline Feeling of choking & 0,000 & 0,000 & 0,000 & 0,026 & 0,613 & 0,057 \\
\hline Hands trembling & 0,000 & 0,004 & 0,000 & 0,701 & 0,764 & 0,423 \\
\hline Feeling shaky/unsteady & 0,000 & 0,000 & 0,000 & 0,736 & 0,804 & 0,844 \\
\hline Fear of losing control & 0,056 & 0,073 & 0,420 & 0,008 & 0,018 & 0,264 \\
\hline Difficulty in breathing & 0,000 & 0,000 & 0,000 & 0,039 & 0,603 & 0,037 \\
\hline Fear of dying & 0,000 & 0,390 & 0,000 & 0,000 & 0,516 & 0,000 \\
\hline Being scared & 0,000 & 0,021 & 0,000 & 0,002 & 0,269 & 0,002 \\
\hline Indigestion & 0,550 & 0,027 & 0,277 & 0,051 & 0,238 & 0,409 \\
\hline Faint/lightheaded & 0,051 & 0,005 & 0,013 & 0,058 & 0,079 & 0,754 \\
\hline Facial flushing & 0,000 & 0,000 & 0,003 & 0,975 & 0,178 & 0,145 \\
\hline Sweating (unrelated to ambient temperature) & 0,378 & 0,021 & 0,097 & 0,424 & 0,775 & 0,456 \\
\hline
\end{tabular}

*P1; Group 1 vs Group 4, P2; Group 2 vs group 4, P3; Group 3 vs group 4, P4; Group 1 vs group 2, P5; Group 1 vs group 3, P6; Group 2 vs group 3.

study, the average of 94 patients followed-up with a diagnosis of subclinical hypothyroidism was found to be 49.1. In these studies, anxiety and depression levels were found to be higher compared to the control group ${ }^{11}$. In another study, the age range of 51 patients was determined as 26-35 years. The authors argued that this age range was selected in order to avoid endogenous depression and to exclude the psychiatric symptoms of patients with menopause ${ }^{8}$. In this study, the average age found was 39.05 years. In addition, in this study, we determined the age range of our patient group to be between 23 and 45 years in order to exclude the effects of menopause and endogenous depression.

In a different study, 32 patients with subclinical hypothyroidism and 29 euthyroid cases were evaluated, and significant increases in the anxiety levels of patients with subclinical hypothyroidism were found compared to euthyroid patients ${ }^{12}$. There are many studies in the literature showing that anxiety levels are higher in patients with thyroid disorders. In addition to this high frequency of anxiety, symptoms of depression in patients with hypothyroidism have been encountered in these studies ${ }^{13}$. In a review, it was shown that hypothyroidism had a significant effect on depression and anxiety, and it was emphasized that it is absolutely necessary to evaluate psychiatric disorders in these patients ${ }^{13}$. Hypothyroidism, subclinical hypothyroidism, and a control group were evaluated in a different study examining the relationship between anxiety and depression with thyroid dysfunction. BAI and BDI scores were found to be significantly higher in both hypothyroid and subclinical hypothyroid patients ${ }^{14}$.

In the literature, there are studies conducted in patients undergoing thyroid hormone replacement therapy for hypothyroidism in whom euthyroidism has been achieved. In a similarly performed study, significant decreases in anxiety and depression scores were demonstrated after treatment in 43 subclinical hypothyroid patients evaluated before and after treatment ${ }^{15}$. However, in a different study, no significant differences in depression scores were found in the evaluation of 89 patients before and after treatment ${ }^{16}$. Again, in a different study, there were no significant differences in the anxiety and depression scores of 38 patients who were evaluated before and after treatment ${ }^{17}$. 
FIGURE 1. BECK ANXIETY SCALE (BAI) MEAN SCORES IN EACH GROUP

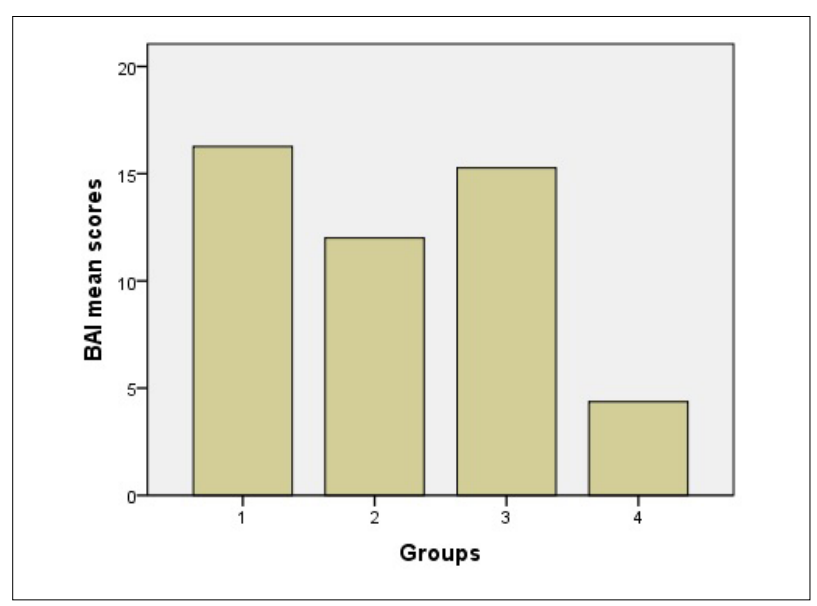

1- Euthyroid patients who were followed-up for 1 year due to thyroid dysfunction (Group 1); 2- Patients with euthyroid status followed-up for at least 5 years due to thyroid dysfunction and who became euthyroid constituted Group

2; 3-Patients with euthyroid status followed-up for at least 10 years due to thyroid dysfunction were included in Group 3 ; 4- The healthy volunteers constituted the control group (Group 4)

In this study, we determined that anxiety and depression scores were higher in patients compared to the control group. However, when the literature is evaluated, the studies are generally based on the comparison of patients with abnormal thyroid function values and euthyroid patients both among themselves and with control groups ${ }^{18}$. In this study, we evaluated patients with hypothyroidism who achieved a euthyroid state with thyroid hormone replacement therapy in consideration of the duration of preexisting diseases. Although several studies in the literature evaluated BAI sub-parameters, we have not found any detailed analysis of these sub-parameters in any study. In this study, we evaluated sub-parameters of the BAI, and in comparison with the control group, we found statistically significant differences in all sub-parameters of the BAI in all patient groups, including hot flushes, weakness, and tremors in the legs, dizziness or drowsiness, palpitations, a feeling of loss of balance, becoming terrified, tremors in the hands, tremor and flushing of the face. However, we have determined that the duration of the disease has no effect on these parameters.

In our evaluation, we found significant statistical differences in all patient groups compared to the control group in terms of the BAI sub-parameter of feeling like choking. In addition, there were significant
FIGURE 2. BECK DEPRESSION SCALE (BDI) MEAN SCORES IN EACH GROUP

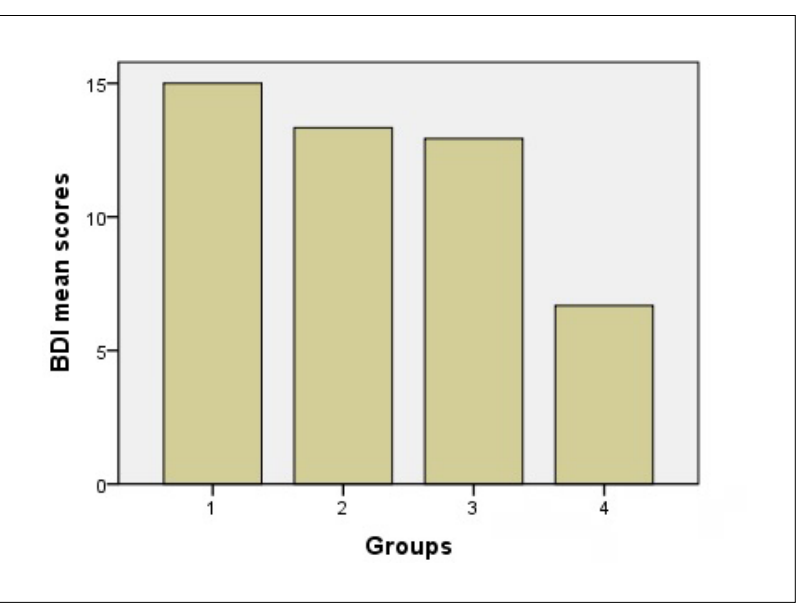

1- Euthyroid patients who were followed-up for 1 year due to thyroid dysfunction (Group 1); 2- Patients with euthyroid status followed-up for at least 5 years due to thyroid dysfunction and who became euthyroid constituted Group2

; 3- Patients with euthyroid status followed-up for at least 10 years due to thyroid dysfunction were included in Group 3 ; 4- The healthy volunteers constituted the control group (Group 4).

differences during the early stages of the disease process compared to the advanced stages of the disease; however, this significant difference disappeared as the years progressed. In addition, when the data of our study is evaluated, significant increases in the frequency of the BAI sub-parameters such as fear of dying and fear of the worst happening in the first year of the disease, compared to the control group.

In the sub-parameters of the BAI such as difficulty in breathing, being terrified, and inability to relax, significant statistical differences were found in all patient groups in relation to the control group. In addition, in the early stages of the disease, increases in the frequency of these three sub-parameters were observed, while these complaints decreased in the following years.

In this study, we could not evaluate the anxiety and depression levels of the patients in the patient groups before and after the treatment or carry out a detailed analysis of the sub-parameters of the BAI. This constituted the limitation of our study. In addition, we suggest that studies should be planned by conducting a detailed analysis of the sub-parameters of the BAI before and after the treatment, which will represent significant adlances in the approach to the patients. In addition, in studies performed considering the thyroid 
autoantibody positivity in patients, the BAI sub-parameters can be evaluated in detail and awareness may be created in the approach to patients. In this study, we evaluated patients who had thyroid dysfunction and became euthyroid with treatment. Patients were predisposed to anxiety and depression even if they were euthyroid. In addition, when the BAI sub-parameters were evaluated in detail, we found that the duration of the significantly affected some anxiety-related symptoms. This suggests that close follow-up of anxiety and depression is necessary even if the patients are euthyroid.

\section{Acknowledgment}

We would like to thank the Scientific Research Support Unit in our faculty for the statistical analysis of the study.

\section{Conflicts of interest \\ None}

\section{Financial disclosures}

None

\section{RESUMO}

OBJETIVOS: Nosso objetivo é determinar os níveis de ansiedade e depressão de pacientes tratados por hipotireoidismo que passaram a um estado eutireoideo. Esses pacientes frequentemente se consultam em clínicas de medicina da família.

METODOLogiA: Este estudo foi realizado em 76 voluntários em estado eutireoideo (grupos de pacientes) que foram tratados por hipotireoidismo e passaram por acompanhamento e 22 voluntários saudáveis (grupo de controle). Foram aplicados questionários a todos os participantes para avaliar os níveis de ansiedade e depressão. O Beck Depression Inventory (BDI) e o Beck Anxiety Inventory (BAI) foram aplicados a todos os grupos. Além disso, os subparâmetros do BAl foram avaliados em detalhe.

RESULTADOS: Pelo menos depressão leve foi detectada em 54,5\% do primeiro grupo, 41,7\% do segundo grupo, e 33,3\% do terceiro grupo. Quando comparadas as pontuações totais do BDI e do BAI dos participantes de diferentes grupos, diferenças estatisticamente significativas foram encontradas. Resultados estatisticamente significantes foram observados em relação a diferentes subparâmetros do BAl entre os grupos de pacientes e em comparação ao quarto grupo.

CONCLUSÃo: Observamos que os pacientes estavam predispostos a ansiedade e depressão, mesmo em estado eutireoideo. Quando os subparâmetros do BAI foram avaliados em detalhe, observou-se que a duração da doença afetou significativamente alguns sintomas relacionados à ansiedade.

PALAVRAS-CHAVES: Ansiedade. Depressão. Doenças da glândula tireoide.

\section{REFERENCES}

1. Fischer S, Ehlert U. Hypothalamic-pituitary-thyroid (HPT) axis functioning in anxiety disorders. A systematic review. Depress Anxiety. 2018;35(1):98-110.

2. Ahmed R. Developmental thyroid diseases and monoaminergic dysfunction. Adv Appl Sci Res. 2017;8(3):1-10.

3. Jonklaas J, Bianco AC, Bauer AJ, Burman KD, Cappola AR, Celi FS, et al. Guidelines for the treatment of hypothyroidism: prepared by the American Thyroid Association task force on thyroid hormone replacement. Thyroid. 2014;24(12):1670-751.

4. Medici M, Direk N, Visser WE, Korevaar TI, Hofman A, Visser Tl, et al. Thyroid function within the normal range and the risk of depression: a population-based cohort study. J Clin Endocrinol Metab. 2014;99(4):1213-9.

5. Eligar V, Taylor PN, Okosieme OE, Leese GP, Dayan CM. Thyroxine replacement: a clinical endocrinologist's viewpoint. Ann Clin Biochem. 2016;53(Pt 4):421-33

6. Biondi B, Cooper DS. The clinical significance of subclinical thyroid dysfunction. Endocr Rev. 2007;29(1):76-131.

7. Reuters VS, Almeida CP, Teixeira PF, Vigário PS, Ferreira MM, Castro CL. Effects of subclinical hypothyroidism treatment on psychiatric symptoms, muscular complaints, and quality of life. Arch Endocrinol Metabol. 2012;56(2):128-36

8. Bathla M, Singh M. Reply to "How prevalent are depression and anxiety symptoms in hypothyroidism?" Indian J Endocrinol Metab. 2016;20(6):883-4.
9. Harshaw C. Interoceptive dysfunction: toward an integrated framework for understanding somatic and affective disturbance in depression. Psychol Bull. 2015;141(2):311-63.

10. Gunes A, Yuzbasioglu Y. Effects of treatment on anxiety levels among patients with benign paroxysmal positional vertigo. Eur Arch Otorhinolaryngol. 2019;276(3):711-8

11. Demartini B, Ranieri R, Masu A, Selle V, Scarone S, Gambini O. Depressive symptoms and major depressive disorder in patients affected by subclinical hypothyroidism: a cross-sectional study. J Nerv Ment Dis. 2014;202(8):603-7.

12. Yarpuz YM, Aydoğan Ü, Sarı O, Aydoğdu A, Üçkaya G, Fenercioğlu A, et al. Subklinik hipotiroidili hastalarda tiroid replasman tedavisinin anksiyete ve depresyon düzeylerine etkisi. Klinik Psikiyatri Dergisi. 2009;12(4):180-7.

13. Pelúcio L, Nardi AE, Ornelas AC, Levitan M. Psychiatric disorders and quality of life in patients with hypothyroidism: a narrative review. | Depress Anxiety. 2016;5(3):241. doi: 10.4172/2167-1044.1000241.

14. Eren I, Cüre E, İnanlı IÇ, Kutlucan A, Köroğlu BK, Tamer MN. Klinik ve subklinik hipotiroidide psikiyatrik belirti düzeyi ve psikiyatrik belirtilerin: tiroid hormon düzeyleri ile ilişkisi. J Cin Psy. 2006;9(3):131-7.

15. Gulseren S, Gulseren L, Hekimsoy Z, Cetinay P, Ozen C, Tokatlioglu $B$. Depression, anxiety, health-related quality of life, and disability in patients with overt and subclinical thyroid dysfunction. Arch Med Res. 2006;37(1):133-9. 
16. Jorde R, Waterloo K, Storhaug H, Nyrnes A, Sundsfjord I, lenssen TG. Neuropsychological function and symptoms in subjects with subclinical hypothyroidism and the effect of thyroxine treatment. J Clin Endocrinol Metab. 2006;91(1):145-53.

17. Baldini M, Colasanti A, Orsatti A, Airaghi L, Mauri MC, Cappellini MD
Neuropsychological functions and metabolic aspects in subclinical hypothyroidism: the effects of L-thyroxine. Prog Neuropsychopharmacol Biol Psychiatry. 2009;33(5):854-9.

18. Dayan CM, Panicker V. Hypothyroidism and depression. Eur Thyroid J. 2013;2(3):168-79. 